\title{
Potret Konformitas dalam Kelompok Remaja Laki-Laki Urban Komunitas BC
}

\author{
Ditha Prasantia,1 dan Sri Seti Indriani $^{\mathbf{b}^{\mathrm{2}{ }^{*}}}$ \\ a,b Universitas Padjadjaran \\ Email: 'dithaprasanti@gmail.com dan ${ }^{2}$ rahadianindri@gmail.com* \\ *corresponding author
}

Keywords:

conformity, group communication, teenage boys, Bandung

Kata Kunci:

konformitas, komunikasi kelompok, remaja laki-laki, Bandung

\begin{abstract}
This article is a research study on communication behavior, especially regarding group conformity and communication motives that occur in urban adolescents. The $\mathrm{BC}$ community is a unique urban teenage boy community as a group of young people who are digitally literate and prioritize the value of conformity in their group. Therefore, the author wants to describe the conformity and motives of adolescents in the community. This study uses the Schutz phenomenology method because it observes the communication behavior of the study of group conformity and male adolescent motives. The results of the research showed that the conformity of the group in the $\mathrm{BC}$ community was formed due to personal factors and situational factors; The motives underlying the male adolescent communication behavior in the $\mathrm{BC}$ community are classified into because of motives and to motives. In the end, the writer found that conformity and motive are two different things but inherent in the individual so that the author can see what trends will be done by male adolescents. This is an impact arising from the conformity and motives they have.
\end{abstract}

\begin{abstract}
ABSTRAK
Artikel ini merupakan kajian penelitian mengenai perilaku komunikasi khususnya tentang konformitas kelompok dan motif komunikasi yang terjadi pada remaja laki-laki urban. Komunitas BC adalah komunitas remaja laki-laki urban yang unik sebagai kumpulan remaja yang melek digital dan mengedepankan nilai konformitas dalam kelompoknya. Oleh karena itu, penulis ingin menggambarkan konformitas dan motif remaja dalam komunitas tersebut. Penelitian ini menggunakan metode fenomenologi Schutz karena mengamati perilaku komunikasi dari kajian konformitas kelompok dan motif remaja laki-laki. Hasil penelitian yang ditemukan menunjukkan bahwa konformitas kelompok dalam komunitas BC terbentuk karena adanya faktor personal dan faktor situasional; motif yang mendasari perilaku komunikasi remaja laki-laki dalam komunitas $\mathrm{BC}$ tersebut digolongkan menjadi because motives dan in order to motives. Pada akhirnya, penulis menemukan bahwa konformitas dan motif merupakan dua hal yang berbeda tetapi melekat dalam diri individu, sehingga penulis pun dapat melihat kecenderungan apa yang akan dilakukan remaja laki-laki. Hal ini sebagai dampak yang timbul dari konformitas dan motif yang dimilikinya tersebut.
\end{abstract}

Copyright (C) 2020 Channel Jurnal Komunikasi. All right reserved. 


\section{PENDAHULUAN}

Konformitas kelompok menjadi hal yang penting untuk diperhatikan dalam kajian psikologi komunikasi kelompok. Hal ini ditunjukkan dengan beberapa penelitian yang menyoroti aspek konformitas. Sanaria menyampaikan tentang konformitas kelompok memiliki karakteristik dan identitas sendiri yang berbeda dengan identitas anggota kelompok. Maka, individu yang menjadi bagian dari kelompok tersebut harus memperlihatkan perilaku, nilai, sikap, dan pola lainnya yang sama dan bisa diidentifikasi sebagai faktor pembeda dari kelompok lainnya. Hal inilah yang disebut dengan konformitas (Sanaria, 2006).

Sementara itu, konformitas juga ditunjukkan oleh remaja yang berada di lingkungan peminum alkohol. Sumarlin menyebutkan bahwa para remaja tersebut memiliki konformitas. Hal ini disebabkan karena remaja tersebut pernah melakukan sesuatu walaupun itu bertentangan dengan hati nurani dan tidak dapat menolak ajakan sesuatu dari temannya dengan tujuan agar bisa diterima oleh teman-temannya (Sumarlin, 2009).

Penelitian tersebut menandakan adanya konformitas yang dimiliki remaja dan pengaruh dari konformitas tersebut. Tetapi berbeda dengan penelitian sebelumnya, dalam tulisan ini, penulis mengkaji konformitas dan motif dari komunitas remaja laki-laki urban. Konformitas dan motif adalah dua hal yang berbeda, tetapi sama-sama melekat dalam diri manusia, dalam hal ini remaja laki-laki tersebut. Inipun yang menandakan kebaruan penelitian ini, adanya konformitas kelompok dan motif yang terdapat pada kaum remaja laki-laki urban. Selain itu, dalam penelitian ini, penulis menceritakan temuan penelitian dengan metode fenomenologi.

Pada dasarnya, literatur penelitian di atas menambahkan nilai kebaruan dengan topik konformitas yang dibahas oleh penulis. Adapun nilai kebaruan yang terdapat dalam penelitian penulis, yang tidak dilakukan oleh beberapa penelitian sebelumnya adalah menitikberatkan pada adanya konformitas kelompok dan motif komunikasi remaja lakilaki urban yang bergabung dalam sebuah komunitas bernama komunitas BC. Hal ini penting karena remaja laki-laki ini tergabung dalam komunitas yang memiliki konformitas dan motif yang unik. Penelitian ini bukanlah sekedar hasil dari keingintahuan penulis, tetapi penulis ingin mengungkapkan bahwa ada kaum remaja laki-laki urban yang tergabung dalam sebuah komunitas, mereka memiliki konformitas dan motif yang melekat dalam diri masing-masing, setelah tergabung dalam komunitas tersebut.

Penelitian lainnya yang diungkapkan mengenai konformitas dan konsep diri juga menguatkan penulis untuk melakukan penelitian ini. Dalam penelitiannya diungkapkan bahwa variabel konsep diri dan konformitas berhubungan secara signifikan dengan perilaku konsumtif pada remaja. Oleh karena itu, konformitas perlu dikaji lebih lanjut dalam kaitan dengan variabel lainnya (Suminar, E., \& Meiyuntari, 2016).

Bahkan, Marks juga melakukan penelitian tentang konformitas, yaitu menguraikan tentang hubungan konformitas dengan proyeksi sosial dalam perilaku remaja yang mengonsumsi alkohol. Hasil menunjukkan bahwa konformitas serta proyeksi sosial terjadi pada sampel 378 anak laki-laki dan perempuan kelas tujuh dan delapan. Sehubungan dengan konformitas, analisis regresi mengungkapkan bahwa perkiraan prevalensi pada kurun waktu tahun pertama memprediksi tingkat penggunaan sendiri alkohol pada tahun kedua, setelah mengontrol penggunaan sendiri pada tahun pertama. Proyeksi sosial ditunjukkan oleh temuan bahwa tingkat penggunaan alkohol sendiri pada waktu tahun pertama memprediksi perkiraan prevalensi pada tahun kedua, setelah mengendalikan perkiraan pada tahun pertama. Data tersebut memperlihatkan adanya hubungan konformitas dengan perilaku remaja laki-laki dan perempuan dalam mengonsumsi alkohol (Marks \& Hansen, 1992).

Menurut Baron dan Byrne (2005:253) pengaruh sosial adalah:

"Social influence occurs whenever our behavior, feelings, or attitudes are altered by what others say or do."

Artinya pengaruh sosial terjadi setiap kali perilaku kita, perasaan, atau sikap yang diubah oleh apa yang orang lain lakukan. Jadi, dalam setiap kelompok akan selalu ada pengaruh sosial yang terjadi, mulai dari perilaku hingga sikap yang ditunjukkan oleh setiap individu dalam sebuah kelompok.

Konformitas dan motif komunikasi, merupakan hal yang mendasari perilaku individu. Penulis juga mencari beberapa kajian terdahulu mengenai motif komunikasi. Dalam penelitiannya yang berjudul I wanted to get to know her better": Adolescent boys'dating motives, masculinity ideology, and sexual behavior, Smiler (2008) mengemukakan bahwa sedikit yang diketahui tentang motif remaja laki-laki untuk berkencan, meskipun penggambaran stereotype menyoroti keinginan untuk perilaku seksual. Data dari 105 anak laki-laki kelas 10 yang beragam, diperoleh bahwa motif yang paling sering mendorong untuk berpacaran dan berhubungan seksual berfokus pada pasangan dan hubungan remaja lakilaki, dan motif remaja laki-laki cenderung konsisten sebagai perilaku seksual. Hasil penelitian tersebut mengungkapkan beberapa hubungan antara motif, ideologi maskulinitas, dan perilaku seksual (Smiler, 2008).

Blumenthal juga mengangkat penelitian tentang motif komunikasi yang berjudul "Social anxiety and motives for alcohol use among adolescents". Dalam penelitian tersebut diungkapkan bahwa kecemasan sosial membuktikan hubungan yang signifikan dalam gangguan penggunaan alkohol dan masalah terkait alkohol. Berdasarkan model motif yang disampaikan dalam Blumenthal meliputi peningkatan, sosial, konformitas, dan coping, semakin banyak kerja 
menunjukkan bahwa individu yang cemas secara sosial dapat mengonsumsi alkohol dalam upaya untuk mengatasi gejala kecemasan mereka. Namun, tidak ada penelitian sampai saat ini yang telah meneliti hubungan ini di antara kaum muda. Dengan demikian, Blumenthal menguji motif penggunaan alkohol sebagai fungsi kecemasan sosial dalam sampel berbasis komunitas dari 50 remaja usia 12 hingga 17 tahun (Mage $=16,35$, SD $=1,10$ ). Seperti yang diperkirakan, kecemasan sosial yang meningkat dikaitkan dengan motif yang berhubungan dengan coping yang tinggi. Poinnya adalah motif penggunaan alkohol lainnya tidak bervariasi sebagai fungsi kecemasan sosial (Blumenthal, , Leen-Feldner, Frala, Badour, \& Ham, 2010).

Kedua literatur penelitian tentang motif di atas, tentu memperkaya referensi penulis dalam melakukan penelitian ini. Betapa pentingnya kajian tentang motif komunikasi yang dapat menghasilkan temuan beragam sesuai objek penelitiannya. Hal ini berarti motif komunikasi yang ditemukan dalam penelitian ini pun bisa jadi berbeda dan memperkaya penelitian yang sudah ada.

Uraian singkat dari beberapa penelitian di atas memperlihatkan pentingnya konformitas kelompok dan motif yang dimiliki remaja laki-laki urban. Penulis melihat urgensi pentingnya dilakukan penelitian ini karena adanya datadata penelitian sebelumnya, bahkan kajian konformitas pun ditunjukkan oleh Marks pada tahun 1992 yang berangsur dilakukan oleh para peneliti lainnya sampai sekarang, sebagai pertanda adanya keberlanjutan yang konsisten dari para peneliti untuk mengkaji aspek konformitas.

Oleh karena itu, nilai kebaruan yang terdapat dalam penelitian penulis, yang tidak dilakukan oleh beberapa penelitian sebelumnya adalah menitikberatkan pada adanya konformitas kelompok dan motif komunikasi remaja lakilaki urban yang bergabung dalam sebuah komunitas bernama komunitas BC. Komunitas BC merupakan komunitas remaja laki-laki urban yang unik karena mereka mengedepankan nilai konformitas yang solid antar anggotanya, sejak mereka bergabung dalam sebuah lembaga belajar bahasa inggris non formal. Inilah yang kemudian diangkat penulis dalam penelitian ini. Konformitas seperti apa yang dijunjung tinggi dalam penelitian ini. Penulis ingin mengungkapkan tentang adanya konformitas kelompok dalam komunitas BC tersebut serta motif komunikasi yang dilakukan para anggota komunitas tersebut.

\section{METODE PENELITIAN}

Penulis menggunakan paradigma konstruktivis yaitu pendekatan kualitatif dengan metode penelitian fenomenologi Schutz, karena ingin mengungkapkan tentang pengalaman para informan secara sadar dari fenomena atau peristiwa komunikasi yang dialaminya, terkait konformitas dan motif komunikasi dalam komunitas remaja laki-laki urban tersebut. Jika merujuk pada literatur, Littlejohn mengatakan bahwa fenomenologi merupakan studi tentang pengetahuan yang berasal dari kesadaran atau cara memahami sebuah peristiwa dengan mengalaminya secara sadar (Littlejohn, 2009).

Hal ini sebagai fokus utama alasan penulis menggunakan metode fenomenologi. Selain itu, penulis menggunakan fenomenologi juga karena ingin mengkonstruksi makna individu dari pengalamannya selama berinteraksi dalam komunitas remaja laki-laki tersebut. Penelitian ini dilakukan selama enam bulan, secara berangsur, penulis melakukan observasi non partisipan dan wawancara kepada para informan. Sebagai kode etik penelitian, penulis juga menyamarkan nama identitas asli dari para informan yang terlibat dalam penelitian ini.

\section{A. Teknik Pengumpulan Data}

Teknik pengumpulan data dalam penelitian kualitatif adalah dengan melakukan observasi, wawancara mendalam, dan studi dokumentasi.

1. Observasi, penulis melakukan pengamatan/observasi dalam penelitian ini dengan cara non participant observation. Penulis mengamati konformitas kelompok dan motif para anggota komunitas tersebut secara non partisipan. Pada mulanya, remaja laki-laki tersebut terlihat enggan karena merasa canggung dan malu. Tetapi penulis pun menyampaikan bahwa penulis menyamarkan identitas asli mereka sebagai informan dalam penelitian ini. Lalu observasi ini dilakukan selama enam bulan, mengamati perilaku para informan dalam komunitas tersebut.

2. Wawancara, penulis melakukan wawancara mendalam kepada informan yaitu anggota komunitas BC, untuk mengecek hasil pengamatan yang telah dilakukan penulis. Wawancara dilakukan dengan cara bervariasi, mulai dari bertemu langsung tatap muka, tetapi dilengkapi juga dengan wawancara menggunakan media sosial "LINE".

3. Penelusuran dokumentasi, penulis mempelajari beberapa penelitian terdahulu dari referensi jurnal-jurnal ilmiah yang terkait serta sumber lainnya yang relevan dengan penelitian yang dilakukan penulis. Penulis membaca referensi jurnal ilmiah nasional maupun internasional, lalu memilih artikel yang relevan dengan kajian penelitian yang dilakukan penulis. Selain itu, penulis juga menggunakan literatur buku metodologi penelitian yang menunjang, untuk membahas tentang metode penelitian fenomenologi dalam artikel ini. 


\section{B. Informan Penelitian}

Dalam penelitian ini, penulis menggunakan teknik pengambilan sampling purposive, yaitu memilih informan yang sesuai dengan kriteria penelitian penulis. Adapun kriteria informan yang digunakan dalam penelitian ini yaitu anggota komunitas BC, yaitu: anggota aktif dalam komunitas BC serta mendominasi proses komunikasi dalam komunitas BC. Komunitas $\mathrm{BC}$ merupakan sebuah perkumpulan kelompok remaja laki-laki yang tinggal di Bandung, terbentuk sejak mereka bergabung dalam lembaga les bahasa asing, lalu mereka sepakat menamai komunitasnya dengan sebutan BC.

Anggota $\mathrm{BC}$ tersebut terdiri dari tujuh orang. Komunitas ini diawali dari keanggotaan mereka sebagai murid dari sekolah bahasa Inggris. Mereka telah saling mengenal satu dengan lainnya. Ketika mereka masih duduk di tingkat sekolah dasar, setelah 7 tahun bersama. Akhirnya, mereka membentuk komunitas tersebut. Mereka terdiri dari tujuh remaja lakilaki. Semenjak itu mereka merasa nyaman dengan komunitas tersebut, dan merasa tidak perlu menerima anggota baru. selanjutnya adalah mereka akan lebih merasa bebas berekspresi. Remaja laki-laki yang menjadi informan penelitian ini berada dalam rentang usia remaja akhir, yaitu 19-22 tahun.

Kategori usia remaja akhir berada pada rentang usia 18-21 tahun (Hurlock, 2003). Pada masa ini individu mulai stabil mulai memahami arah hidup, menyadari dari tujuan hidupnya, serta memiliki pendirian tertentu. Adapun beberapa informan dalam penelitian, sebagai berikut:

1. EK, ketua komunitas BC

2. DJ, anggota komunitas $\mathrm{BC}$

3. AN, anggota komunitas BC

4. ID, guru sekolah bahasa dari anggota komunitas BC

\section{HASIL PENELITIAN}

Merujuk pada hasil wawancara mendalam dan observasi yang telah dilakukan, penulis melihat adanya fenomena menarik dalam penelitian ini. Remaja laki-laki urban merupakan objek penelitian yang disoroti dalam penelitian penulis, hal ini karena fenomena tentang remaja laki-laki urban yang menarik untuk diteliti. Penulis ingin mengungkapkan konformitas kelompok dan motif komunikasi yang dilakukan para remaja laki-laki urban.

Sebagai remaja laki-laki yang tinggal di perkotaan, perilaku komunikasi yang ditunjukkan pun berbeda dengan remaja laki-laki rural. Inipun dikuatkan oleh hasil penelitian Umaroh, Kusumawati, \& Kasjono (2015). Hasil penelitian Umaroh dkk (2015) menyebutkan bahwa terdapat perbedaan perilaku seksual berisiko di urban area dan rural area pada tahun 2012. Remaja laki-laki maupun perempuan yang tinggal di daerah urban (perkotaan) lebih banyak melakukan perilaku seksual berisiko, seperti berpegangan tangan, ciuman dan petting. Hal ini dipengaruhi oleh faktor kegagalan fungsi keluarga, pengaruh media dan rendahnya pendidikan nilai agama (Umaroh, Kusumawati \& Kasjono, 2015).

Seperti dijelaskan di atas, terdapat perbedaan dari segi sosial budaya antara urban dan rural area, hal ini pun menjadi alasan menarik perlunya dilakukan penelitian ini. Penulis ingin mengungkapkan konformitas kelompok yang terjalin dalam komunitas remaja laki-laki urban. Jika penelitian Umaroh, Kusumawati \& Kasjono (2015) mengatakan bahwa remaja laki-laki urban cenderung individualis, penulis tidak melihat hal tersebut terjadi pada objek penelitian penulis, yaitu anggota komunitas $\mathrm{BC}$.

EK, informan penelitian penulis yang merupakan anggota komunitas BC menyampaikan pernyataannya tentang konformitas kelompok yang dirasakan nya dalam komunitas tersebut, berikut ini adalah penuturannya.

"Aku enjoy bergabung di komunitas BC ini, ya karena udah kenal sejak lama, bersahabat, terus kita bikin komunitas, jadi punya hobi dan kebiasaan yang sama. Aku juga ngerasa teman-teman ya solid, kita saling mendukung jadi termotivasi gitu, hehe...tapi sih kalo sekarang karena kita udah komitmen dari awal, kita mau nikah muda, jadi termotivasi untuk itu, hehe..." (EK, anggota komunitas BC, wawancara pribadi, 2019).

DJ, sebagai anggota komunitas BC juga menyampaikan hal yang sama tentang pengalaman komunikasinya yang terjalin dalam komunitas tersebut. Menurut DJ, ketika komunitas tersebut dibentuk, mereka juga merasa sangat terbantu dengan kehadiran media sosial. Berikut ini kutipan wawancaranya.

"Aku sih jadi ngerasa ada medsos tuh jadi ada wadah atau tempat gitu, hehe...jadi komunikasi antar anggota BC makin intens dan kompak, haha... kita bisa ngebahas hal apapun gitu, kita juga punya tempat bertukar pikiran. Tapi yang pasti, komunitas BC ini ya bikin aku termotivasi juga buat nikah muda, hehe...” (DJ, anggota komunitas BC, wawancara pribadi, 2019).

Konformitas kelompok dalam komunitas BC tersebut juga terbangun karena adanya kesamaan hobi dalam topik pembicaraan tentang percintaan, seks, wanita, dan persahabatan. Mereka juga membicarakan tentang gambar perempuan, yang diambil dari media sosial lainnya, kemudian gambar tersebut dikomentari dan dibahas, mereka menuangkan pemikiran mereka mengenai gambar perempuan tersebut.AN, sebagai informan penelitian penulis juga menyampaikan bahwa mereka memiliki kesamaan dalam hal topik diskusi, berikut ini adalah penuturannya. 
"Ya, kami emang satu visi, karena punya hobi yang sama, kalau ngobrol dan diskusi tuh nyambung klop... yang kami obrolin ya seputar percintaan, perempuan, hehe...soal fisik perempuan, tapi pada intinya ya kami jadi saling mempengaruhi, ada nilai baru, eh ada simbol baru gitu, misalnya kalo kami mau ngumpul, kami pake istilah "kmb" yuk..." (AN, anggota komunitas BC, wawancara pribadi, 2019).

Ungkapan AN di atas, sama halnya dengan para informan lainnya menegaskan munculnya konformitas kelompok yang terbentuk dalam komunitas BC. Konformitas kelompok tersebut juga ditandai dengan adanya penerimaan para informan sebagai anggota komunitas BC dalam menggunakan nilai-nilai baru yang diakui oleh para anggotanya. Jadi, penulis pun menemukan adanya istilah baru dalam komunitas BC, yaitu "KMB" merupakan singkatan dari konferensi meja bundar, simbol yang dimaknai oleh mereka sebagai suatu ajakan untuk bertemu.

Topik pembicaraan mengenai perempuan menjadi hal yang paling utama dibicarakan dalam komunitas BC, sehingga mereka pun melakukan kegiatan "fantasi". Namun, dua informan mengungkapkan bahwa ketika berfantasi tentang perempuan, itu hanya sebatas dalam percakapan saja, jadi bukan suatu keinginan yang akan mereka lakukan.

Mereka membentuk suatu skenario ketika mereka akan bertemu, di mana, kapan serta apa yang akan mereka lakukan, khususnya ketika salah satu dari mereka ada yang baru "jadian” atau sedang "berulang tahun".

Berdasarkan pengakuan dari para informan selama observasi dan wawancara yang dilakukan penulis bahwa sebagian besar yang dibicarakan lebih cenderung tentang pernyataan-pernyataan yang berhubungan dengan seks, mulai dari istilah-istilah seks hingga pada fantasi tentang seks yang dianggap ekstrim oleh mereka. Hal ini pun menjadikan konformitas kelompok dalam komunitas BC semakin kuat. Oleh karena itu, melalui hasil wawancara dan observasi tersebut, penulis menggambarkan bahwa konformitas kelompok dalam komunitas BC terbentuk karena adanya faktor personal dan faktor situasional.

1. Faktor personal, rasa nyaman yang dirasakan karena kesamaan hobi dalam topik pembicaraan tentang percintaan, seks, perempuan, dan persahabatan. Rasa nyaman tersebut menyebabkan para informan sebagai remaja laki-laki memiliki rasa takut terhadap penyimpangan dan celaan sosial.

2. Faktor situasional, kekompakan kelompok yang terjalin dalam komunitas BC merupakan bagian dari faktor situasional yang menguatkan konformitas kelompok bagi para anggota komunitas BC. Selain itu, adanya keterikatan pada penilaian bebas juga mendasari konformitas yang dimiliki oleh para informan sebagai anggota komunitas BC.

Penelitian yang dilakukan Lee, Neighbors, \& Woods (2007) menggambarkan hasil penelitiannya tentang motif yang berjudul “Marijuana motives: Young adults' Reasons for Using Marijuana” bahwa motif pemakaian ganja di kalangan remaja dan orang dewasa, sebagian besar karena tidak terlepas dari penggunaan alkohol. Penelitian ini dirancang untuk mengidentifikasi motif pemakaian ganja dari perspektif pengguna. Responden penelitian ini adalah siswa SMA yang berjumlah 634 siswa, memberikan alasan lain. Alasan yang paling sering dilaporkan termasuk kesenangan / kesenangan, penyesuaian diri, eksperimentasi, peningkatan sosial, kebosanan, dan relaksasi. Metode analisis regresi yang digunakan mengungkapkan bahwa eksperimen secara konsisten terkait dengan penggunaan ganja yang lebih sedikit, sedangkan kesenangan, kebiasaan, peningkatan aktivitas akan berubah dikaitkan dengan penggunaan ganja yang lebih berat dan karena faktor masalah/stres (Lee, C. M., Neighbors, C., \& Woods, 2007).

Tetapi penelitian di atas melihat motif dari metode penelitian kuantitatif, berbeda halnya dengan penelitian yang dilakukan penulis. Penulis melihat dari perspektif subjektif dengan menggunakan metode penelitian fenomenologi agar memperoleh data yang relevan dari hasil wawancara dan observasi yang mendalam.

ID, sebagai guru di sekolah bahasa, tempat di mana para informan mulai membentuk komunitas BC, juga menegaskan tentang adanya perilaku para muridnya sebagai remaja laki-laki. Berikut ini adalah hasil wawancara dengan ID.

"Ya, saya ngerasa juga ada yang beda dengan para murid saya ini, karena mereka lain dari yang lain. Mereka berkelompok, sejak lama, sejak bergabung dari SD sampai mau masuk kuliah ya, terus anehnya, mereka juga pada kompak kalo mereka komitmen mau pada nikah muda," (ID, anggota komunitas BC, wawancara pribadi, 2019).

Jika melihat penuturan ID di atas, penulis melihat adanya motif komunikasi yang dimiliki remaja laki-laki yang bergabung dalam komunitas BC tersebut. Penulis dapat menggambarkan motif komunikasi para informan dalam tabel di bawah ini. 
Tabel 1.1

Motif Perilaku Komunikasi para anggota komunitas BC

\begin{tabular}{|c|c|c|c|}
\hline No & Informan & Because Motive & In Order to Motive \\
\hline 1. & EK & $\begin{array}{l}\text { Kesamaan hobi dalam membicarakan } \\
\text { percintaan, seks, perempuan, dan } \\
\text { persahabatan }\end{array}$ & $\begin{array}{l}\text { Berfantasi tentang seks dan } \\
\text { perempuan, kekompakan dan } \\
\text { motivasi menikah muda }\end{array}$ \\
\hline 2. & DJ & $\begin{array}{l}\text { Rasa nyaman yang muncul karena } \\
\text { menyukai pembicaraan dan berfantasi } \\
\text { tentang seks, perempuan, dan percintaan }\end{array}$ & Motivasi menikah muda \\
\hline 3. & AN & $\begin{array}{l}\text { Kesamaan hobi dalam membicarakan } \\
\text { masalah percintaan, seks, dan perempuan }\end{array}$ & Keinginan menikah muda \\
\hline
\end{tabular}

(Sumber: Olahan Peneliti, 2019)

Berdasarkan tabel di atas, penulis melihat bahwa motif komunikasi yang muncul dalam diri informan, mayoritas hampir sama, karena mereka memiliki kesamaan hobi membicarakan masalah seks, perempuan, dan percintaan. Oleh karena itu, because motives ini mendorong para anggota komunitas memiliki in order to motives yang sama, yaitu kecenderungan perilaku ingin menikah muda.

Dalam bagian ini, penulis ingin menganalisis konformitas kelompok dalam komunitas BC. Jika dianalisis dari terjalinnya konformitas kelompok, Sears (2004) menyebutkan ada 4 faktor yang mempengaruhi konformitas, yaitu:

1. Rasa Takut terhadap Celaan Sosial

Alasan utama konformitas adalah demi memperoleh persetujuan, atau menghindari celaan kelompok. Dalam komunitas BC ini, penulis melihat rasa takut terhadap celaan sosial ini merupakan bagian dari faktor personal. Mereka memiliki konformitas yang kuat, sehingga rahasia antar anggota pun terjaga aman, mereka berusaha agar pembicaraan dalam komunitas BC pun aman, sehingga dibentuklah beberapa nilai dan simbol baru agar orang lain tidak memahaminya.

2. Rasa Takut terhadap Penyimpangan

Rasa takut dipandang sebagai individu yang menyimpang merupakan faktor dasar hampir dalam semua situasi sosial. Penulis melihat rasa takut tentang penyimpangan ini adalah bagian dari faktor personal para anggota komunitas BC. Mereka menjaga rahasia dalam kelompok mereka, saling meyakinkan bahwa hal yang mereka lakukan adalah benar.

3. Kekompakan Kelompok

Kekompakan yang tinggi menimbulkan konformitas yang semakin tinggi. Hal ini adalah bagian dari faktor situasional yang terjalin antar anggota komunitas BC.

4. Keterikatan pada Penilaian Bebas

Hal ini pun merupakan bagian dari faktor situasional, karena para anggota komunitas memperlihatkan konformitas kelompok yang terjalin dalam komunitasnya semakin kuat. Bahkan, gurunya sebagai informan dalam penelitian ini juga memiliki penilaian bahwa mereka unik, sehingga semuanya termotivasi untuk menikah muda.

Berkaitan dengan motif perilaku komunikasi, penulis menganalisis dengan fenomenologi yang diungkapkan oleh Schutz. Campbell (1994) mengungkapkan bahwa Schutz mempertanyakan tentang arti dunia sosial untuk aktor/subjek yang diamati, dan makna yang terkandung dibalik tindakannya. Jika dikaitkan dalam penelitian ini bahwa para informan pun sebagai aktor yang diamati tentang motif komunikasi dari pengalaman yang mereka lakukan.

Ajiboye (2012) mengungkapkan juga bahwa Schutz juga memeriksa kehidupan bathiniyah individu yang direfleksikan dalam perilaku sehari-harinya. Schutz meletakkan manusia dalam pengalaman subjektif dalam bertindak dan mengambil sikap dalam kehidupan sehari-hari. Dalam hal ini, Ajiboye menyampaikan Schutz juga melihat bahwa manusia mempunyai kemampuan untuk menentukan akan melakukan apapun yang berkaitan dengan dirinya atau orang lain.

Hal ini tercermin dalam motif komunikasi yang dilakukan oleh para informan. Para informan memiliki kemampuan untuk melakukan apapun yang disepakati oleh kelompoknya, sehingga terbentuklah hal tersebut sebagai because motives dan in order to motives.

Hal menarik lainnya yang ditemukan penulis adalah tentang kebiasaan berfantasi para anggota komunitas BC.

"Ya, walopun aku dan temen-temen di komunitas punya kebiasaan fantasi, tapi itu sebatas dalam percakapan aja, ya sebatas fantasi, kami gak melakukan yang aneh-aneh, karena kami punya iman, jadi itu ya batasan buat kami, batasan untuk gak berbuat tindakan dosa gitu, "(EK, anggota komunitas BC, wawancara pribadi, 2019). 
Menurut pengakuan dua orang informan bahwa meskipun mereka memiliki kebiasaan baru "berfantasi tentang seks dan perempuan", tetapi itu sebatas pemikiran mereka, mereka tidak sampai melakukannya. Ketika ditanyakan mengenai alasannya, dua orang informan tersebut mengaku bahwa mereka masih memiliki iman, mereka beranggapan bahwa itu sebagai batasan dalam bertindak, untuk tidak keluar dari norma sosial dan kaidah lainnya bagi mereka untuk tidak berbuat hal yang tidak sewajarnya dilakukan.

\section{KESIMPULAN}

Hasil penelitian ini mengungkapkan bahwa konformitas kelompok dalam komunitas BC terbentuk karena adanya faktor personal dan faktor situasional; motif yang mendasari perilaku komunikasi remaja laki-laki dalam komunitas BC tersebut digolongkan menjadi because motives, misalnya berupa rasa nyaman yang muncul karena menyukai pembicaraan dan berfantasi tentang seks, perempuan, dan percintaan; serta in order to motives, yaitu munculnya keinginan yang sama dalam pemikiran para informan untuk menikah muda. Pada akhirnya, penulis menemukan bahwa kajian konformitas dan motif merupakan dua hal yang berbeda, tetapi keduanya sangat melekat dalam diri individu. Konformitas dan motif sangat penting untuk dikaji karena hal tersebut menentukan apa yang akan dilakukan oleh individu saat ini dalam beberapa waktu ke depan.

\section{DAFTAR PUSTAKA}

[1] Ajiboye, E. O. (2012). Social Phenomenology of Alfred Schutz and the Development of African Sociology. (British Journal of Arts and Social Sciences, Vol.4. No.1 2012).

[2] Baron, R.A. dan Byrne, D. (2005). Psikologi sosial. Edisi kesepuluh: jilid 2. Erlangga.

[3] Blumenthal, H., Leen-Feldner, E. W., Frala, J. L., Badour, C. L., \& Ham, L. S. (2010). Social anxiety and motives for alcohol use among adolescents. Psychology of Addictive Behaviors, 24(3), 529.

[4] Campbell, T. (1994). Tujuh Teori Sosial, Sketsa, Penilaian, dan Perbandingan. Kanisius.

[5] Hurlock. (2003). Psikologi Perkembangan. Jakarta: Erlangga.

[6] Lee, C. M., Neighbors, C., \& Woods, B. A. (2007). Marijuana motives: Young adults' Reasons for Using Marijuana. Addictive Behaviors, 32(7), 1384-1394.

[7] Littlejohn, S. W. \& K. A. F. (2009). (2009). Teori Komunikasi. (edisi 9. J).

[8] Marks, G., Graham, J. W., \& Hansen, W. B. (1992). Social projection and social conformity in adolescent alcohol use: A longitudinal analysis. Personality and Social Psychology Bulletin, 18(1), 96-101., 18(1).

[9] Sanaria, A. (2006). Conformity and Norms: The Individual Perspective. http://papers.ssrn.com/sol3/pape rs.cfm?abstract_id=2150900, 18 Oktober 2014.

[10] Sears. (2004). Psikologi Sosial. Erlangga.

[11] Smiler, A. P. (2008). "I wanted to get to know her better": Adolescent boys' dating motives, masculinity ideology, and sexual behavior. Journal of Adolescence, 31(1), 17-32., 31(1).

[12] Sumarlin, R. (2009). Perilaku konformitas pada remaja yang berada di lingkungan peminum alkohol. Jurnal Psikologi Universitas Gunadarma: Jakarta.

[13] Suminar, E., \& Meiyuntari, T. (2016). Konsep Diri, Konformitas dan Perilaku Konsumtif pada Remaja. Persona: Jurnal Psikologi Indonesia, 4(02).

[14] Umaroh, A. K., Kusumawati, Y., \& Kasjono, H. S. (2015). Hubungan Antara Faktor Internal Dan Faktor Eksternal Dengan Perilaku Seksual Pranikah Remaja Di Indonesia (Analisis Data Sdki 2012) (Doctoral dissertation, Universitas Muhammadiyah Surakarta). 
